The Historical Journal, 64, 4 (2021), pp. 940-962 (C) The Author(s) 2021. Published by Cambridge University Press. This is an Open Access article, distributed under the terms of the Creative Commons Attribution-NonCommercial-NoDerivatives licence (http://creativecommons.org/licenses/by-nc-nd/4.0), which permits non-commercial re-use, distribution, and reproduction in any medium, provided that no alterations are made and the original article is properly cited. The written permission of Cambridge University Press must be obtained prior to any commercial use and/or adaptation of the article.

doi:10.1017/Soo 18246 X2000o62X

\title{
THE CONGRESS SYSTEM AND THE FRENCH INVASION OF ALGIERS, $1827-183 \mathrm{O}^{*}$
}

ERIK DE LANGE

Utrecht University

A BSTRACT. The Congress system that arose in Europe after the Napoleonic Wars facilitated European imperial expansionism throughout the nineteenth century. Yet, the ties between that system and expansionism have rarely been unwound and studied in detail. Taking the French invasion of Algiers in I 830 as a case in point, this article shows how the Congress system's shared discourses of security and threat perceptions as well as its common practices of concerted diplomacy fostered European imperialism in North Africa. The article emphasizes obscured continuities and understudied multilateral diplomatic efforts. It uncovers the ways in which the post-I 815 system decisively shaped the aims, justifications, and execution of the French war against Algiers. European, North African, and Ottoman actors each furthered or contested the idea that the invasion was part of an international legacy dating back to the Congress of Vienna, related to the concerted repression of North African 'Barbary piracy'. In bringing these connections to light, it becomes apparent that the post-I 8 I 5 international system cannot be understood in isolation from nineteenth-century imperialism.

\section{I}

Conquest and imperial expansionism were at the heart of the international system that arose in Europe after the Revolutionary and Napoleonic Wars.

Utrecht University, Drift 6, 35I2BS Utrecht, The Netherlands e.delange@uu.nl

* I would like to thank Professor Beatrice de Graaf, Dr Ozan Ozavci, Dr Moritz Föllmer, Dr Christopher Mapes, and Remzi Çăgatay Çakırlar as well as the editors and anonymous reviewers of the Historical Journal for their helpful feedback on earlier drafts of this article. The organizers of the Consortium on the Revolution Era's conference in Atlanta, GA, gave me a first opportunity to present the argument in 2019. I am also indebted to Filiz Yazicioglu for her assistance with the archives in Istanbul. My research was funded by the European Research Council under the European Union's Seventh Framework Programme (FP/2007-2013) / ERC Grant Agreement n.615313. 
The ever-expanding literature on the so-called Congress system tends to discuss its impact from an entirely European perspective. It notes that the system kept the peace among former enemies, heralded a new era of multilateral governance, and forcefully cracked down on continental revolutions. ${ }^{1}$ How this system also supported imperialism and colonial domination beyond the continent and across the globe has received less attention. ${ }^{2}$ Yet, matters of imperialism and colonial rule made it onto the agendas of nineteenth-century congresses. The Congress system facilitated European expansionism and did much more than bring peace to the continent.

While some works situate particular imperial developments within the frameworks of this system - such as the reinstatement of Dutch colonial authority in Indonesia or the Latin American wars of independence - the 'systemic' facilitation of imperialism through shared practices and collective understandings of legitimate violence, diplomatic concertation, and, especially, security has remained obscure. ${ }^{3}$ Edward Ingram's oft-cited essay 'Bellicism as boomerang' stands out as an exception. Still, it teaches us little about how the new diplomatic frameworks facilitated imperial expansionism. 4 The French invasion of Algiers in 1830 is a case in point. Its ties to the international system remain unclear, even though the invasion's causes, underlying incentives, planning, and execution were all shaped by the Congress system. This article analyses the international dynamics behind the French imperial venture into North Africa and argues that the post-1815 system cannot be understood in isolation from European imperialism.

The literature on 1830 still treats the topic primarily from a national or unilateral perspective. Scholars perceive the invasion as a domestic matter of France, Algeria, or the Ottoman Empire. Ottoman historians discuss the invasion of Algiers in terms of the empire's internal struggles. Historians of Algeria and France, for their part, tend to consider the attack in light of national issues, domestic political manipulations, and internal concerns - predominantly within the French metropole. 5 These narratives typically draw from Charles-André

${ }^{1}$ For an overview of the recent Congress system historiography, J. Kwan, 'Review article: the Congress of Vienna, 1814-1815: diplomacy, political culture, and sociability', Historical Journal, 6 o $(2017)$, pp. $1125^{-46 .}$

${ }^{2} \mathrm{~J}$. Osterhammel, The transformation of the world: a global history of the nineteenth century (Princeton, NJ, and Oxford, 2014), pp. 396 and 402.

3 N. van Sas, Onze natuurlijkste bondgenoot: Nederland, Engeland en Europa, $I_{1} 8_{3^{-I}} 8_{3} I$ (Groningen, 1985); B. de Graaf, Fighting terror after Napoleon: how Europe became secure after I8I5 (Cambridge, 2020). For a 'systematic' analysis, P. Schroeder, The transformation of European politics, I $76_{3}-1848$ (Oxford, 1994), p. xii.

4 E. Ingram, 'Bellicism as boomerang: the Eastern Question during the Vienna System', in P. Krüger and P. Schroeder, eds., 'The transformation of European politics, $176_{3}-1848^{8}$ ': episode or model in modern history? (Münster, 2002), pp. 205-25.

5 For the Ottoman Empire, V. Aksan, Ottoman wars, I 70o- 1870 : an empire besieged (Harlow, 2007), pp. 363-4. For Algeria, L. Merouche, Recherches sur l'Algérie à l'époque ottomane, II: La course: mythes et réalité (Saint-Denis, 2007), pp. $15^{-16}$; J. McDougall, A history of Algeria (Cambridge, 2017), pp. 50-1. 
Julien's Histoire de l'Algérie contemporaine, which maintains that the invasion was ultimately an attempt of the faltering Bourbon monarchy to overcome parliamentary opposition and popular unrest. The attack on Algiers had to provide much-needed martial bluster to the royal regime and help stave off defeat in the 1830 elections. Of course, this ultimately failed when the July Revolution ended the Restoration monarchy. ${ }^{6}$ Though Julien does take into account diplomatic negotiations and international relations, his historiographical legacy brought more attention to internal factors. Most authors still predominantly focus on the domestic causes behind the invasion. 7 Notably, David Todd and others have recently suggested that the French war against Algiers should be studied from a transnational perspective. ${ }^{8}$ Despite this historiographical call, the bulk of the literature remains blind to the importance of the international system.

Few have analysed the invasion of Algiers in a 'systemic' manner. Indeed, historians of the Congress system often signal its end in the late 1820 , when the system turned into a more loosely institutionalized Concert of Europe as large multilateral meetings of the kind initiated at the Congress of Vienna became increasingly rare. Moreover, they have only cast brief glances at the system's impact beyond the European continent. 9 In his The transformation of European politics, Paul Schroeder does list the invasion and subsequent occupation of Algeria as an example of 'how the Vienna system...worked to manage crises, preserve general peace, and maintain a balance of satisfactions among the major actors', but deems these crucial events a mere 'sideshow' to the history of the Congress system. ${ }^{10}$ In fact, the post-Napoleonic international system made the invasion possible. French officials explicitly situated their endeavours in a longer international legacy dating back to 1815 . Ottoman and Algerine actors' conduct owed much to their earlier encounters with concerted European diplomacy, particularly during the Greek Revolution (1821-30). Furthermore, statesmen in Europe judged the looming invasion on the basis of the norms, practices, and idioms that arose under the Congress system - even if that system had started to change by 1830 .

${ }^{6}$ C.-A. Julien, Histoire de l'Algérie contemporaine, I: La conquête et les débuts de la colonisation (I827-I87I) (2nd edn, Paris, 1979), pp. 31 and 59.

7 J. Sessions, By sword and plow: France and the conquest of Algeria (Ithaca, NY, and London, 2011). One exception is E. le Marchand, L'Europe et la conquête d'Algèr: d'après des documents originaux tirés des Archives de l'État (Paris, 1913).

${ }^{8}$ D. Todd, 'A French imperial meridian, 1814-1870', Past E' Present, 210 (201 1), pp. 155-86, at p. 161 ; H. Blais, 'Pourquoi la France a-t-elle conquis l'Algérie'; and J. Dakhlia, '183o, une rencontre ?', in A. Bouchène, J. Peyroulou, $\mathrm{O}$. Tengour, and $\mathrm{S}$. Thénault, eds., Histoire de l'Algérie à la période coloniale (I830-1962) (Paris and Algiers, 2012), pp. 52-7 and 142-8.

${ }^{9}$ For instance, M. Jarrett, The Congress of Vienna and its legacy: war and great power diplomacy after Napoleon (London and New York, NY, 2013), pp. $34^{8-} 5^{\text {o. }}$

${ }^{10}$ Schroeder, Transformation, pp. 710-11. 
This article emphasizes previously neglected continuities and restores a sense of historical contingency to the events in question. ${ }^{11}$ In so doing, I will scrutinize contemporary understandings of diplomacy and analyse the legitimizing narratives that preceded the invasion. Diplomatic, military, and non-state actors repeatedly utilized discourses of collective security, invoked perceptions of threat, and debated specific security practices. They tapped into discourses and diplomatic repertoires that had developed in the wake of 1815 , when a new 'security culture' took shape in Europe. This security culture revolved around new multilateral institutions and diplomatic forms, such as ambassadorial or ministerial conferences. It was also based on common understandings of security threats, interests, and practices. ${ }^{12}$ Positioning the French invasion within that security culture can better explain how the international system fostered French imperial expansionism into North Africa. Algiers's image and reputation as a lair of 'Barbary pirates' and a menace to Europe permeated diplomatic negotiations. This perceived threat had been already exaggerated by the end of the $181 \mathrm{os}$, but nevertheless gained new prominence during the revolution in Greece. Still, French claims of acting for the 'disinterested' sake of security in the Mediterranean drew upon this threat perception to justify imperial agendas. Drawing from French, British, Austrian, Dutch, and Ottoman archives, this article shows how the post-1 815 system shaped the invasion plans at different crucial stages, from the outbreak of war between France and Algiers in 1827 to the departure of the expeditionary army in May 1830 .

\section{I}

The invasion of Algiers began with a slap, or so the story often goes. On 29 April 1827 , Hussein Dey (r. 1818-30), the regent of the Ottoman vassal state of Algiers, hit French consul general Pierre Deval (1758-1829) three times with a fly-whisk. What had started as a customary courtesy visit to mark the beginning of Ramadan turned sour when Deval and Hussein Dey began to discuss the contentious issues of international loans, territorial concessions, and maritime warfare. Following an exchange of accusations and insults, Hussein Dey 'lifted himself from his seat', as Deval recounted, 'and waving the handle of his flywhisk gave me three forceful blows to my body.' ${ }_{13}$ Hussein would later remember the moment differently, reminiscing that he had made 'two or three light strokes with the fly-whisk that happened to rest in my humble hands'. ${ }^{14}$ Regardless of the slap's intensity, Deval left Algiers shortly thereafter. The

${ }^{11}$ M. Abbenhuis, An age of neutrals: great power politics, I 8I5-I9I4 (Cambridge, 2014 ), p. 42.

${ }^{12}$ B. de Graaf, I. de Haan, and B. Vick, 'Vienna 1815: introducing a European security culture', in B. de Graaf, I. de Haan, and B. Vick, eds., Securing Europe after Napoleon: 18 I5 and the new European security culture (Cambridge, 2019), pp. 1-18.

${ }^{13}$ Deval to Damas, 3o Apr. 1827, Nantes, Centre des Archives diplomatiques (CADN), $22 \mathrm{PO} / 1 / 5$ o.

${ }^{14}$ Julien, La conquête, p. 27. 
French government then declared a war, a long naval blockade began, and a force of 37,000 soldiers landed on Algerine shores three years later. Yet, the place of these events in relation to the Congress system and its security culture can only be grasped by looking back to 1815 , when Algiers was first presented as a shared threat to European security.

The Congress of Vienna of $1814^{-1} 5$ ended the Napoleonic Wars and engendered a reordering of the European continent, but it also changed European attitudes towards the Regency of Algiers, opening the door to later imperial ventures. Non-state activists and small power diplomats argued at the congress that the return of peace had to terminate the 'perpetual warfare' carried out by the privateering fleets of Algiers, and the other 'Barbary Regencies' of Tunis and Tripoli. ${ }^{15}$ Alarmed by an upsurge of corsair captures and backed by the abolitionist outcry against the slave trade, these congress attendees portrayed the privateering of the North African Regencies as an illegal affront, a piratical threat to the security of 'European commerce', and a disgrace to the captured 'Christian sailors' held in slavery. According to these activists, the threat to Europe warranted concerted repressive action. ${ }^{16}$ Similar calls had been made throughout the eighteenth century, but after 1815 they could have a larger impact, as a new international system of collective security made such concerted action possible. ${ }^{17}$

Soon after the Congress of Vienna and the creation of the Quadruple Alliance between Great Britain, Russia, Prussia, and Austria in November 1815 , concerted means of engaging with the North African Regencies began to take shape. Despite the initial reluctance of Britain's and Austria's senior statesmen, the 'Barbary pirate' threat remained on the international agenda for years. It featured in the deliberations of subsequent international meetings, such as a series of ambassadorial conferences in London (1816-23), the Congress of Aix-la-Chapelle (1818), the Congress of Troppau (1820), and the Congress of Verona $(1822) .{ }^{18}$ Naval and diplomatic actors carried multilateral decisions into effect with various concerted interventions, including the Anglo-Dutch bombardment of Algiers (1816), the creation of a SpanishDutch maritime alliance (1816-24), great power communications to the Sublime Porte in Istanbul (1819), and an Anglo-French diplomatic expedition to the Regencies (1819). As a result, the intensity and scale of North African

\footnotetext{
${ }^{15}$ For the corsairs as an anomaly, [F. Tidemann], Was könnte für Europa in Wien geschehen?: beantwortet durch einen Deutschen (n.p., 1814).

16 D. Panzac, Barbary corsairs: the end of a legend, I 800-I820 (Leiden and Boston, MA, 2005), pp. 75-6; B. Vick, The Congress of Vienna: power and politics after Napoleon (Cambridge, MA, 2014), pp. $213^{-22}$.

17 A. Thomson, Barbary and Enlightenment: European attitudes towards the Maghreb in the eighteenth century (Leiden and New York, NY, 1987).

18 B. Vick, 'Power, humanitarianism and the global liberal order: abolition and the Barbary corsairs in the Vienna Congress system', International History Review (2017), pp. 1-22. For the Congress of Troppau, C. Mapes, 'Germany and the question of slavery, $175^{\mathrm{O}-1} 8_{5} \mathrm{O}^{\prime}$ (unpublished dissertation, Vanderbilt University, 2018), pp. 168-70.
} 
privateering dropped significantly after a rather sudden and extraordinary upsurge in $1814^{-1} 5^{19}$ Over the course of these years, European diplomats not only blurred the conventional distinctions between sanctioned, statesponsored maritime warfare (privateering, or corsairing) and illegal raiding at sea (piracy), but they also devised shared modes of countering threats and practising security. A set of diplomatic conventions arose in which security practices would be legitimated by multilateral decisions (preferably reached at a congress or ambassadorial conference), regulated by treaties, pursued in a spirit of 'disinterest', and increasingly controlled by the continent's great powers (of the Quadruple Alliance and, gradually, France). ${ }^{20}$ These systemic characteristics of rules, norms, and practices all had a decisive influence on the French plans to invade Algiers.

In tandem with the creation of a new international system in Europe, political elites in the North African Regencies and Istanbul increasingly became aware and increasingly cautious - of the European powers' new concerted security practices. Most of the European interventions against 'Barbary piracy' coincided with domestic unrest, as the drawn-out aftermath of the Napoleonic Wars, domestic revolts, an outbreak of the plague, and economic hardships made it perilous and difficult to meet European demands. ${ }^{21}$ North African and Ottoman actors opposed successive calls to end corsairing by invoking internal security concerns, sovereign rights of belligerency, and established treaty relations dating back to the seventeenth century. ${ }^{22}$ For instance, when two English and French commissioners visited Algiers in 1819, Hussein Dey asked whether he had not the right to wage war on his enemies, and wondered if he 'should burn all his vessels, as from the nature of their representations, they would become entirely useless?' 23 North African privateering became almost moribund as it petered out. ${ }^{24}$ The perceived threat of 'Barbary piracy' nevertheless remained, even with privateering much reduced. Local contestations of European security efforts kept this threat perception alive, which became crucial for the 1830 invasion.

The endurance of Algerine corsairing in the face of its international repression even informed the fated clash between Deval and Hussein Dey in April 1827. Historians often veer between two causes of the conflict, emphasizing either the question of the unpaid 'Bacri loans' dating back to a series of

19 Panzac, Barbary corsairs, pp. 76 and 289-9o.

${ }^{20}$ M. Schulz, Normen und Praxis: Das Europäische Konzert der Großmächte als Sicherheitsrat I 8 I 5 I860 (Munich, 2009), pp. 68, 143-4, and 547 .

${ }^{21}$ A. Yaycioglu, Partners of the empire: the crisis of the Ottoman order in the age of revolutions (Stanford, CA, 2016); K. Chater, Dépendance et mutations précoloniales: la Régence de Tunis de ${ }_{1} 8 I_{5}$ à I 857 (Tunis, 1984), pp. 267-72; Panzac, Barbary corsairs, pp. 306-7.

${ }^{22}$ Liston to Castlereagh, 6 Aug. 1819, Kew, The National Archives (TNA), FO 78/92, fos. 209-12.

${ }_{23}$ Detail of the commissioner's second audience with the Dey of Algiers, 9 Sept. 1819, TNA, FO 8/3, fos. $176-9$.

${ }^{24}$ M. Belhamissi, Histoire de la marine algerienne (15 I6-1830) (Algiers, 1983), pp. 159-68. 
grain imports in $1793^{-8}$, or the construction of armed fortifications on the La Calle trade post during the $1820{ }^{25}$ Yet, both clarifications tend to reduce the importance of maritime raiding as a perceived threat to European security. From 1825 onwards, Algerine corsairs again carried out privateering wars against Europe's weaker maritime powers, particularly the Papal States, which possessed no warships at all. ${ }^{26}$ The Holy See turned to France for protection, and Deval soon received instructions to negotiate a treaty with Algiers on the papacy's behalf. This 'Roman affair', as Hussein Dey called it, was the first topic he and Deval spoke about on the day of the fly-whisk incident. ${ }^{27}$

The 'Roman affair' holds dual importance for linking the French conflict with Algiers to the Congress system. First, Algerine corsairing against papal ships kept alive the established notion of a 'Barbary pirate' threat to Europe. Secondly, it invoked the issue of great power protection. The latter directly touched upon questions of status and rank within the system. Assuming the role of protector over a junior maritime partner was one of the ways in which great power status could be asserted. A decade earlier, the French consul in Tunis had tried to do the same for the Kingdom of the Two Sicilies, only to be outclassed by his British counterpart. ${ }^{28}$ Things had changed by 1827 . French officialdom became increasingly assertive in its attempts to revive the nation's old, pre-Revolutionary commercial preponderance and diplomatic influence on the other side of the Mediterranean. ${ }^{29}$ Events in North Africa thus matched the broader French misgivings over a perceived inferiority of rank vis-à-vis the other great powers. With the days of the allied occupation $\left(1815^{-18)}\right.$ behind it, France took on prestigious military ventures such as the intervention to quell revolution in Spain in $1823.3^{\circ}$ By offering protection and mediating on behalf of the Papal States, French actors also donned the garb of a great power in Algiers, edging closer to the members of the Quadruple Alliance. This later strengthened French claims of acting for broader European interests.

French conduct during the war initially did not bring this sought-after international prestige. Following Deval's departure from the Regency on 11 June, Algerine troops commenced hostilities by razing the newly constructed armaments on the trade post of La Calle. ${ }^{31}$ The French war effort, meanwhile, consisted of a blockade of Algiers and the Regency's other ports that commenced

\footnotetext{
${ }^{25}$ For the loans, Julien, La conquête, pp. 18-21. On the concessions, D. Todd, 'Retour sur l'expédition d'Alger: les faux-semblants d'un tournant colonialiste français', Monde(s), 10 (2016), pp. $205^{-22 .}$

${ }^{26}$ Rostan to Deval, 23 Sept. $1826, \mathrm{CADN}, 22 \mathrm{PO} / 1 / 67$.

${ }^{27}$ Deval to Damas, 3o Apr. $1827, \mathrm{CADN}, 22 \mathrm{PO} / 1 / 5 \mathrm{O}$.

${ }^{28}$ Devoize to Richelieu, 6 Feb. 1816, CADN, $712 \mathrm{PO} / 1 / 51$, no. 18.

${ }^{29} \mathrm{~J}$. Clancy-Smith, Rebel and saint: Muslim notables, populist protest, colonial encounters (Berkeley, CA, 1997), p. 7 o.

$3^{\circ}$ M. Price, "Our aim is the Rhine frontier": the emergence of a French forward policy,

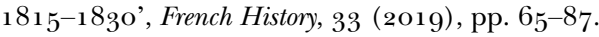

${ }^{31}$ Belhamissi, Histoire de la marine algerienne, pp. 16o-1.
} 
on 16 June and would last for three years. French statesmen thought that Algiers could not endure long and presented repeated ultimatums. Yet, Hussein Dey held out patiently, even as the number of warships blockading Algiers increased from seven to twelve to eighteen vessels. $3^{2}$ Intended to cut off the Regency's trade and keep its fleet in check, the French blockade managed to achieve neither objective.33 Several Algerine corsairs broke the line of warships, posing an immediate threat to French commerce. As early as July, Algerine corsairs began taking merchant vessels. This provoked much international amusement and mockery aimed at the French. Britain's consul in Algiers reported that France appeared 'to have been the only sufferer by the war'. 34 His American counterpart, remembering the Revolutionary Wars, sardonically concluded: 'The French understand well being blockaded, but not to blockade.' 35

In France, popular opinion turned against the war and called for more forceful action. With its members bearing most of the brunt of inefficient convoy services and rising freight costs, the chamber of commerce of Marseille communicated merchant grievances and lobbied for remedies. ${ }^{6}$ It thus helped direct state policy at a time when the government of Prime Minister Joseph de Villèle (r. 1821-8) did not seem to be particularly concerned with the war against Algiers. Instead, the ministry gave precedence to affairs in Spain and Greece, with the latter reaching a particularly critical phase around the signing of the London Convention. 37 The first suggestions to change strategy and take a more assertive stance against the Regency came from the merchant lobby and representatives in the Chamber of Deputies. In the latter, Pierre-Honore de Roux from Marseille lambasted the 'passive war' and its detrimental effects on the economy of the southern departments. He argued that a military expedition would end Algerine maritime raiding for good. ${ }^{8}$ Like-minded members of the parliamentary opposition delivered several speeches and memoranda in July 1828, criticizing the costly blockade and calling for an invasion on land.39 These proposals had little immediate effect. They certainly prefigured later changes, when official support for a military expedition gradually materialized.

The early years of the war between France and Algiers portended the invasion. From its earliest beginnings, matters of rank in the hierarchical post-

$3^{2}$ Julien, La conquête, p. 29.

33 Belhamissi, Histoire de la marine algerienne, pp. 159-6o.

34 St John to Huskisson, 10 May 1828 , TNA, FO $112 / 3$, fos. $245^{-6}$.

35 Biddle to Lee, 23 Oct. 1829, College Park, MD, National Archives and Records Administration, 59, M23, vol. 12.

${ }^{36}$ For instance, [?] to chamber of commerce Marseille, 23 July 1827, Marseille, Archives de Chambre de Commerce, MR.4.6.1.4.1/o2; chamber of commerce Marseille to Guys, 11 Sept. $1827, \mathrm{CADN}, 712 \mathrm{PO} / 1 / 181$.

37 Julien, La conquête, p. 30 .

${ }_{38}^{8}$ G. Weiss, Captives and corsairs: France and slavery in the early modern Mediterranean (Stanford, CA, 2011 ), pp. $165^{-6 .}$

39 Julien, La conquête, p. 29. 
1815 international system defined the conflict. French attempts to assert its great power standing helped provoke the clash between Deval and Hussein Dey. The 'Roman affair' made this most apparent, while domestic frustrations and foreign mockery brought the issue of status even more to the forefront. In addition, the endurance of Algerine corsairing - first against Europe's weakest maritime powers, then also to the detriment of France - allowed French actors to position their designs against Algiers in a lineage of European security efforts against the threat of 'Barbary piracy'. These matters of status and threat only became more important when a new French government got behind the rising calls for an invasion, and soon had to defend its new policies abroad.

\section{I I}

The official war plans drafted in Paris from 1827 onwards represent a good starting point for an analysis of the international considerations behind the invasion. French statesmen binned the first of these plans without much debate, as the Villèle government favoured the wait-and-see strategy of the enduring blockade. Still, the plans warrant historical analysis because they clarify how French foreign policies were conceived in direct relation to the post-1815 international system. Foreign onlookers, merchant lobbyists, and parliamentary speakers had already given voice to issues of international status and security at sea. These issues remained prominent as the official plans for an invasion of Algiers developed between October 1827 and March 1830 , along with arguments for collective security and disinterest that had to legitimize them to foreign governments.

Being frustrated about the blockade, the minister of war, Aimé Marie Gaspard de Clermont-Tonnerre $\left(1_{779-1865}\right)$, issued the conflict's first proposal for an intervention on land. Clermont-Tonnerre's report was a lengthy critique of a navy that lay 'powerless' before Algiers and maintained that only an invasion could bring the war to a 'glorious' conclusion. The memorandum noted the futility of trying to reach a diplomatic solution to end the conflict, as 'there is no security with the government of Algiers, except in its destruction'. Clermont-Tonerre then went on to enumerate the benefits of an invasion, stating that it would bolster the monarchy and allow the government to face the ballot box confidently, with 'the keys of Algiers in hand'.40 Few members of the royal council felt the same enthusiasm when they discussed the plan on 14 October 1827 . Villèle merely noted that the report would surely prove useful if such an expedition could be executed, and the king closed matters by telling Clermont-Tonnerre: 'you see, we are in the minority'. ${ }^{1}$

$4^{\circ}$ Rapport au Roi sur Alger, 14 Oct. 1827 , Vincennes, Service historique de la défense (SHD), GR 1/H/1.

$4^{1} \mathrm{P}$. Azan, 'Le rapport du marquis de Clermont-Tonnerre sur une expédition à Alger (1827)', Extrait de la Revue Africaine, 340-1 (1929), pp. 1-47, at p. 5 . 
Despite its rejection, Clermont-Tonnerre's report is usually discussed in the literature as a blueprint for the invasion in its final form. Historians look upon the 'keys of Algiers' remark as further proof that the attack primarily served a domestic agenda. $4^{2}$ Yet, this emphasis relegates another crucial characteristic of the proposal to the background: its engagement with the post-1815 international system. Clermont-Tonnerre asserted that France would be doing a service to Europe in attacking Algiers, delivering the continent from three centuries of 'humiliating vexations' at the hands of the 'Barbary pirates'. 43 While he stressed the domestic benefits of obtaining military glory ahead of the elections, Clermont-Tonnerre also noted that such glory could not be attained on the European continent. Europe was at peace, he argued, calling the situation a sign of 'Providence' that France now had the opportunity to wage war elsewhere. 44 From its dismissal of Algiers as a nuisance that had to be eliminated for the sake of European security, to its affirmation of the continental territorial order, Clermont-Tonnerre's memorandum situated the proposed invasion squarely within the frameworks laid out under the Congress system.

Whereas Clermont-Tonnerre's proposal subscribed to the territorial arrangements of 1815 , later French strategizing took a more revisionist approach towards the territorial order that the Congress of Vienna construed. These new plans for the war against Algiers, however, only came about two years after the dismissal of Clermont-Tonnerre's suggestions. By then, in August 1829, Charles X had formed a new government with more conservative inclinations, manned by staunchly monarchist and anti-liberal ultraroyalists. One of them was Prince Jules de Polignac (1780-1847), who served as the government's head and minister of foreign affairs. Polignac shared the conviction that a military victory could help raise the monarchy's popularity. $45 \mathrm{He}$ also advocated the idea that the nation had been robbed of its 'natural borders' at the Congress of Vienna, when it lost the Rhineland to Prussia. Polignac's views resembled a very common reading of international affairs in Restoration France, crossing otherwise stark ideological boundaries between Bonapartists and royalists. $4^{6}$ With his proposal, Polignac further radicalized the schemes to return the Rhineland to France. Yet, he soon discovered that he had to redirect such expansionist efforts away from Europe and towards Algiers, as the Vienna order remained solid.

The minister's initial roadmap towards territorial aggrandizement in Europe - the so-called 'plan de Polignac' - has acquired infamy in the literature. This infamy explains why historians have failed to recognize its links to

$4^{2}$ Sessions, By sword, p. 25; Julien, La conquête, p. 31.

43 Rapport au Roi sur Alger, 14 Oct. 1827 , SHD, GR 1/H/1.

44 Ibid.

45 A. Pingaud, 'Le projet Polignac (1829)', Revue d'histoire diplomatique, 14 (1900), pp. 402-10, at pp. $403-4$.

$4^{6}$ Price, 'French forward policy', p. 69. 
the invasion of Algiers. 47 Compiled at the height of the Russo-Turkish war of 1828-9, when many European statesmen thought the fall of the Ottoman Empire was immanent, the Polignac plan exploited this crisis situation by proposing a complete overhaul of Europe's territorial order. Polignac set his scheme against a backdrop of Ottoman spoils that could be divided and an Eastern Question that had to be resolved. France, his plan held, would allow Russia and Austria to take parts of Ottoman Europe, so it could in return expand to its 'natural frontiers' by annexing the southern Netherlands and Rhineland. The other European powers would each be compensated accordingly: Prussia could take the northern Netherlands, Britain would get the Dutch colonies, and the territory-stripped King William I would be reimbursed for his losses with a new throne in Constantinople, reconceived as a Christian city-state $4^{8}$ 'Absurd' or 'fantastical' as it may seem to present-day historians, the plan passed the royal council. St Petersburg would be informed first - that is, until the Treaty of Adrianople on 14 September 1829 suddenly ended the Russo-Turkish war.49

At this point, with its grandiose plan discarded, the Polignac ministry turned to Algiers as a place where military victory, martial bluster, and expansionist gains could be obtained for the Bourbon monarchy-if only because it lay beyond Europe and the territorial order that had been created at the Congress of Vienna. The peace between Russia and the Ottoman Empire closed off the options for enlargement in Europe. The end of the RussoTurkish war brought French expansionist aims more in line with the established system of collective security. Though some French officials hoped that conquests elsewhere could in the future be traded for the Rhineland or Belgium, they nevertheless directed their expansionism away from the European continent, across the Mediterranean. $5^{\circ}$

The government in Paris then considered more assertive action against Algiers. This shift in foreign policy did not originate in the metropolitan circles of political decision-making, but rather came from the Mediterranean seaboard and regional consular network. News of an incident in the bay of Algiers, where a French warship under a flag of truce accidentally received fire when its commanding admiral tried to negotiate an armistice, provoked further official dismay over alleged affronts to the nation's dignity. ${ }^{1}$ More importantly, a diplomatic agent arrived in Paris in September 1829 with elaborate plans to end these affronts once and for all. This man was the

\footnotetext{
47 Price, 'French forward policy', pp. $84^{-5}$; Schroeder, Transformation, p. 659 .

$4^{8}$ Mémoire lu et approuvé au Conseil du Roi (Septembre 1829), [n.d.], La Courneuve, Centre des Archives diplomatiques (CADLC), $112 \mathrm{CP} / 178$, fos. $287-90$.

49 Pingaud, 'Le projet Polignac', pp. 408-9. On the plan's similarities to earlier French policies, Price, 'French forward policy', pp. $84-5$.

$5^{\circ} \mathrm{K}$. Hammer, Die französische Diplomatie der Restauration und Deutschland, ${ }_{1} 8_{14}{ }_{1} 8_{3} \mathrm{O}$ (Stuttgart, 1963), pp. 221-2.

$5^{1}$ Julien, La conquête, pp. 33-4.
} 


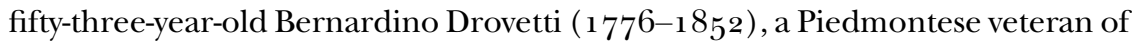
Napoleon's Egyptian campaign. He had entered the French consular service, acquired a fortune by trading in antiques, and now brought along a daring, ambitious plan to defeat Algiers. $5^{2}$

This incredibly influential proposal had unique features. Yet, it also drew from the familiar arguments of furthering European interests. Drovetti's contribution centred upon enlisting the support of the Egyptian viceroy Mehmed Ali (1769-1849), who could attack Algiers at the cost of only some political, financial, and naval support. Unlike a French invading army, Drovetti maintained, Mehmed Ali's forces would be welcomed by the populace of Algiers as fellow Muslims. This would pose less of a concern to the British cabinet. Best of all, for French interests, the Egyptian troops could also take possession of Tunis and Tripoli on their way to Algiers, bringing an immediate end to all 'piratical' endeavours of the 'Barbary Regencies'.53

Polignac liked the ideas and arranged their discussion in the royal council. At that meeting, several additional reports provided further arguments for the scheme and reiterated the plan's international appeal. One memorandum noted that the campaign against Algiers, Tunis, and Tripoli would be of interest 'to all maritime states... [which] more or less suffer from the piracy of these powers'. European nations, the text continued, would finally be able to maintain stable relations with authorities in North Africa, doing away with the remaining bilateral peace treaties that purportedly were under the constant threat of sudden suspension. ${ }^{54}$ The congregated ministers and Charles $\mathrm{X}$ favoured the prospect of destroying Algiers and countering British ascendancy in the Mediterranean with the help of a strong ally in North Africa-all while allegedly acting for the sake of European interests. 55 The council adopted Drovetti's plan and began preparing its immediate execution.

French officialdom thus started to work towards a final resolution of the war with Algiers from late September 1829, particularly by trying to garner international approval. Before it turned to the capitals of Europe's great powers, the Polignac government first solicited support from the Sublime Porte in Istanbul. Within a broader diplomatic context of anxieties over the stability of the Ottoman Empire and its implications for European security, it was clear to French statesmen that great power acceptance of Drovetti's plan with Mehmed Ali was going to depend upon the consent of Sultan Mahmud II $\left(1785^{-1839}\right)$. Only a firman (an order or binding decree) from Mahmud

$5^{2}$ D. Reid, Whose Pharaohs?: archaeology, museums, and Egyptian national identity from Napoleon to World War I (Cairo, 2002), pp. 37-9 and $4^{6 .}$

53 V. Puryear, France and the Levant: from the Bourbon Restauration to the Peace of Kutiah (Berkeley and Los Angeles, CA, 1941), pp. 113-14; G. Douin, Mohamed Aly et l'expédition d'Alger (I 829-I83o) (Cairo, 1930), pp. v-xiv.

54 Aperçu de la situation politique de l'Egypte en 1828 et 1829 par Mr. de Coehorn, [n.d.], CADLC, $17 \mathrm{MD} / 19$, fos. $107^{-20}$.

55 Ibid. 
could alleviate the plan's troublesome, contestable aspects. Without it, the venture amounted to arming a rebel to the empire's central authority in an illegal effort to subdue three of the sultan's nominal vassals. Polignac admitted the entire expedition would be unthinkable within Europe, but that in North Africa one would have to judge things according to a different order of ideas'. $5^{6}$ Once more, Polignac situated the measures against Algiers in direct relation to the modes, principles, and regulations of conducting international affairs that had arisen in Europe after 1815 .

To Ottoman authorities, such invocations of the international system carried little legitimacy. The French ambassador in Istanbul, Armand Charles Guilleminot $\left(1774^{-1840}\right)$, tried to solicit a firman by calling on persisting European efforts to end 'Barbary piracy', and failed miserably. A memorandum that he handed over to the reis efendi (the Porte's equivalent of a foreign affairs minister) termed the regents in North Africa '[the] real rebels to the authority of the Sublime Porte' because they engaged in 'the most infamous piracy' and were 'the shame of Islam'. Besides instrumentalizing the notion of a pirate threat, the text also drew on previous security practices by arguing that 'Europe' had long been involved in a 'project' to end this piracy. The sultan, the message concluded, could now help bring this 'project' to a beneficial conclusion. If not, it stated menacingly, France was going to act anyway, whether it had support from Istanbul or not.57 After receiving the document in a noncommittal manner, the reis efendi declared at a second audience that the firman would not be issued. The Porte rejected all foreign encroachments on the North African vassal states, especially if they were carried out with the help of Mehmed Ali, and reasserted the sultan's suzerainty over these domains. The sultan pledged to exert his sovereign powers to help mediate by sending an envoy to Algiers, in order to bring this conflict over 'trivial issues' to an end. $5^{8}$ In the wake of European interventions assisting insurgent Greece and various earlier infringing attempts to end North African corsairing, it is little wonder that Ottoman officials in Istanbul understood references to European projects and security not as legitimation but rather as intimidation. 59

Facing official rejection, the French government could no longer maintain that it acted in accordance with Mahmud II's interests. More so, the Sublime Porte's reply affirmed his sovereignty over the Regency, which further complicated French ambitions. The problem was not that Mehmed Ali felt he needed a firman from Istanbul. The Egyptian viceroy repeatedly expressed his 'utter contempt' for Mahmud II to French and British diplomats, echoing the tensions that had arisen between the two during the Greek Insurgency and

$5^{6}$ Polignac to Montemart, 19 Jan. 183 o, CADLC, $2 \mathrm{MD} / 7$, fos. $4^{-9}$.

57 Memorandum remis au Reis Effendi, 1 Dec. 1829 , CADN, 166PO/E/159.

$5^{8}$ Statement of Vizier to Sultan Mahmud II, 1245 Ş. 29 [23 Feb. 183o], Istanbul, Türkiye Cumhuriyeti Cumhurbaşkanlığı Devlet Arşivi, I.DUIT 139/3.

59 O. Ozavci, Dangerous gifts: imperialism, security, and civil wars in the Levant, $1798-1864$ (Oxford, forthcoming). 
foreshadowing the later conflicts of the Eastern Crisis $\left(183_{1-41)}{ }^{6 o}\right.$ Nor did the statesmen of Russia and Prussia appear to care too much. St Petersburg and Berlin immediately professed their support for the plan involving Mehmed Ali. Tsar Nicholas (1796-1855) instantly noted that this effort could finally end Mediterranean piracy. The Prussian minister of foreign affairs, Count Günther von Bernstorff (1769-1835), agreed that his country would derive 'great advantage' from the destruction of the Regencies as Prussia lacked a navy to protect its merchants from corsairing. ${ }^{61}$ These quarters accepted the legitimizing narratives of fighting 'Barbary piracy' and finishing a European project of security. As Polignac had expected, such approval came less easily from Vienna and London.

During the ongoing attempts to amass great power support, which took place in tandem with negotiations in Istanbul and Alexandria, French actors found their plans least welcomed by Austrian and British officials. Their exchanges and clashing notions of acceptable security practices shed further light on the workings of the international system. Britain's secretary of foreign affairs, George-Hamilton Gordon, earl of Aberdeen $\left(1784^{-1860)}\right.$, argued that the French scheme went against all principles of legitimacy. Metternich called it a plan 'without basis' ${ }^{62}$ Both men feared that the French collaboration with Mehmed Ali could further destabilize the Ottoman Empire and endanger European peace.

In response to the French claims, Lord Aberdeen maintained that the British had done things very differently in 1816 . Back then, he noted, the country concerted with its continental allies to bombard Algiers and abolish 'Christian slavery'. ${ }^{6}$ The members of the cabinet found France's venture disproportionate to the insults suffered at the hands of Hussein Dey and suspected that the involvement of Mehmed Ali served as a ploy for French regional dominance. Or, as Prime Minister Arthur Wellesley, duke of Wellington (1769-1852), told the French ambassador in London: 'this would not be deemed a very desirable mode of getting rid of piracy'. ${ }^{6}$ One thing nevertheless became apparent in these dispersed negotiations. The ardent opponents in Great Britain and Austria still accepted the argument's essence that France would suppress the threat of 'Barbary piracy' and further European security, even if they found the means objectionable. ${ }^{65}$

Further diplomatic debates over the proposed expedition took place in Istanbul and Alexandria, where they soon acquired a multilateral character.

6o Mimaut to Polignac, 27 Nov. 1829, CADLC, 6CCC/23, Politique no. 5; Barker to Aberdeen, 8 Mar. 1830 , TNA, FO 78/192, fos. 97-112.

61 Mortemart to Polignac, 6 Oct. 1829 , CADLC, $112 \mathrm{CP} / 178$, fos. $144^{-5}$; Mortier to Polignac, 3o Jan. 1830 , CADLC, $106 \mathrm{CP} / 273$, fos. $3{ }^{-}-9$.

62 Metternich to Appony, 5 Feb. 183o, Vienna, Österreichisches Staatsarchiv, Haus-, Hof-, und Staatsarchiv (HHStA), StAbt, Frankreich, Diplomatische Korrespondenz, 276, fos. $21-2$.

${ }^{6}$ Laval to Polignac, 8 Feb. 183 o, CADLC, 8CP/629, fos. $155^{-62 .}$

64 Aberdeen to Stuart de Rothesay, 26 Jan. 1830, TNA, FO 27/405, fos. 11-12.

65 J. Serres, La politique turque en Afrique du Nord sous la Monarchie de Juillet (Paris, 1925), p. 19. 
British and Austrian representatives, united by their governments' opposition to the French plans, worked together to ward off the looming attack. In Istanbul, diplomatic agent Robert Gordon (1791-1847) and internuncio Franz von Ottenfells $\left(177^{-1} 8_{5} 1\right)$ received orders to co-operate. They had to back the Ottoman authorities and urge them to hurry with their envoy to Algiers. ${ }^{66}$ In Alexandria, the British consul John Barker (1771-1849) had to impress Mehmed Ali of the 'serious consequences' that resulted from an unauthorized attack on the North African Regencies. The Egyptian viceroy replied that he did not want to get into a conflict with a coalition of powers, and asked: 'Have not the European states a sufficient guarantee in my character that Piracy would cease to be practised?' 67 Hostility from the great powers concerned the Egyptian viceroy. At an earlier occasion, he had inquired whether he could expect French protection against Great Britain. The Polignac government was not willing to provide this, offering only vague promises of 'good offices'. ${ }^{68}$ Shunned from French support, Mehmed Ali then proposed an alliance with Britain during his talks with Barker, but the cabinet in London had no interest. ${ }^{69}$ The Egyptian viceroy sought to exploit divisions in the ranks of the European great powers to obtain foreign support for his own expansionist aims, but failed to do so, and the Drovetti scheme of subduing Tripoli, Tunis, and Algiers faltered accordingly. ${ }^{\circ}$

By March 1830, contemporaries could surmise that the proposed attack involving Mehmed Ali was not going to take place. Too much international hostility existed. At the same time, parliamentary and ministerial opposition to the plan had grown in France..$^{71}$ More importantly, French officials had no success in aligning the plan's claims of fighting piracy and fostering security with the established norms and customs of the post-1815 international system. The plan appeared illegitimate and dangerous to British and Austrian statesmen, especially when Sultan Mahmud II withheld his firman. Historians now tend to see the international scheming of the Polignac government as signs of the French willingness to upend the order established under the Congress system. $7^{2}$ Yet, what the diplomatic sources rather strikingly indicate is the ultimate French unwillingness to risk a war among the great powers.

Appearing to act for broader European interests and finding ways to get great power support remained a more important task for French diplomacy than

66 M. Šedivý, Metternich, the great powers and the Eastern Question (Pilsen, 2013), pp. 414-16; Metternich to Ottenfels, 4 Feb. 183 o, HHStA, StAbt, Türkei VI, 51, fos. 33-40; Foreign Office to Barker, 29 Jan. 1830 , TNA, FO $78 / 192$, fos. $1-4$.

67 Barker to Aberdeen, 8 Mar. 1830 , TNA, FO 78/192, fos. 97-112.

68 Puryear, France and the Levant, pp. 123-4.

69 Barker to Aberdeen, 8 Mar., 12 Mar., 22 June, and 6 July 183o, TNA, FO 78/192, fos. 97-112, 113-16, $211-20,25^{\mathrm{O}-2 .}$.

$7^{\circ}$ Claiming that this had been Mehmed Ali's aim all along, Douin, Mohamed Aly, p. xcii.

$7^{1}$ Puryear, France and the Levant, pp. 123-4; Julien, La conquête, pp. 37-8.

$7^{2}$ Price, 'French forward policy', pp. 65-6; Sedivý, Metternich, p. 411. 
most of the historiography has recognized. Successive schemes to bring the war to a 'glorious' end consistently referenced European security and the purported threat of Algerine 'piracy'. The use of that threat perception was more than argumentative window-dressing. It also invoked a lineage of internationally sanctioned security efforts. French actors thus sought to bring their expansionist schemes in line with the post-1815 system and its security culture. How the workings of the international system facilitated the execution of such plans becomes clear when examining the final months before the departure of the French expeditionary army.

\section{V}

The final preparation of the invasion provoked frenzied activity in France. Historians have written many pages about troop movements, mobilizing speeches, liberal critiques, and royalist festivities between early March and 25 May 1830 , when the French fleet set sail for Algiers from Toulon.73 Yet, an intense diplomatic effort to garner international support also characterized these weeks. French actors maintained a continuous correspondence with virtually all European capitals. There was even a proposal to convene a conference. The French suggestion to hold a European conference concerning the future of Algiers is a particularly important indication of the invasion's ties to the post1815 system. It features fleetingly in the historiography, with Miroslav Šedivy's more substantial discussion as one of the sole recent exceptions. 74 The conference proposal has never been analysed in relation to the concerted politics that took shape under the Congress system. However, scrutinizing the proposal makes the significance of collective security for the 1830 expedition apparent.

First of all, the timing of French official communications during these crucial months underlines the importance of collective security. As early as 6 February, French ambassadors across the continent had to float the option that France might take on Algiers alone. 75 In comparison, the oft-cited and much-maligned speech in which Charles X informed the Chamber of Deputies of the upcoming expedition took place almost a month later, on 2 March. The speech itself fully supports the dominant reading of the 1830 invasion as a domestic affair. The monarch threatened to suspend the Charter (the constitution) in order to prevent the 'criminal manoeuvres' of the opposition and preserve 'public peace' ${ }^{7}$ Still, this announcement of a unilateral attack on Algiers ought to be seen in unison with the diplomatic efforts that the Polignac ministry pursued in Europe. The French issued a circular to all European courts on

${ }^{73}$ For instance, Sessions, By sword, pp. 35-40.

74 Šedivý, Metternich, pp. 430-1; Serres, La politique turque, pp. 39 and $5^{1-2}$.

75 Circular to French ambassadors, 6 Feb. 183o, CADLC, 2MD/4, fo. 217.

${ }^{7}$ V. Beach, Charles X of France: his life and times (Boulder, CO, 1971), pp. 307-9; Julien, La conquête, pp. 37-9; Sessions, By sword, pp. 19-26. 
12 March, when the Mehmed Ali scheme was definitely off the table, presenting new plans to end the war with Algiers. 77

Secondly, invocations of common European security concerns, again, characterized this diplomatic message. The circular used the established trope of a 'Barbary pirate' threat that hampered the peaceful commerce and safe navigation of European powers in the Mediterranean Sea. A direct attack on the Regency, the circular noted, was the only way in which piracy could be 'definitively destroyed', Christian slavery 'absolutely abolished', and the payment of tributes for peace treaties finally 'suppressed'. $7^{8}$ The message closed by inviting the governments to offer support and concert with the French.

Lastly, the fact that the Polignac ministry directly addressed Europe's smaller powers with the circular as well offers compelling evidence for the importance of collective security. The second-rank states (such as the Netherlands or Spain) and third-rank powers (Italian principalities or Hanseatic cities) were, after all, the ones that still bore the brunt of North African maritime raiding. They would therefore be most likely to back the French claims for this reason alone. At the same time, support from the smaller European powers would help isolate the enduringly sceptical governments of Great Britain and Austria. We cannot truly grasp the European dynamics behind the 1830 invasion without attention to these smaller powers and their supporting role.

Favourable replies to the new French proposal soon arrived. The monarchs and statesmen of Tuscany, the Two Sicilies, Portugal, and the Netherlands expressed their support for the invasion at a moment's notice. Each power subscribed to the claim that 'Barbary piracy' would be brought to an end.79 Pope Pious VIII (r. March 1829-November 1830) bestowed the endeavour with his blessing. ${ }^{80}$ The Sardinian cabinet in Turin even offered to set up a complementary invasion of Tunis in response to the circular. Unlike the other responses, the French government found little endearment to this suggestion. ${ }^{81}$

The great powers were less eager to accept the French proposal. The lines of division between enthusiastic approval and anxious scepticism remained much the same as they had during the earlier stages of the conflict. Tsar Nicholas supported the invasion and even offered the French ambassador in St Petersburg whatever military intelligence on Algiers the imperial archives contained. ${ }^{82}$ In contrast, the Prussian minister Von Bernstorff, once positive about the earlier plans, now began to voice concerns over the opposition of British and Austrian statesmen. While he liked the idea that piracy would end, he also

\footnotetext{
77 Circular to French diplomats, 12 Mar. 1830 , CADLC, 2 MD/7, fos. $32-5$.

$7^{8}$ Ibid.

79 Extract of Moussaye to Polignac, 13 Feb. 1830 , Consini to [?], 19 Feb. 1830 , De la None to Polignac, 23 Feb. 183 o, Lapasse to Polignac, 23 Feb. 1830 , excerpt from Blanchet to Polignac, [n.d.], CADLC, $2 \mathrm{MD} / 4$, fos. 231, 248-9, 257-8, 259-62, and $265^{-6 .}$

80 Cardinal Albani to Bellocq, 29 Feb. $18_{3}$, CADLC, $2 \mathrm{MD} / 4$, fo. 254.

${ }^{81}$ Chasteau to Polignac, 26 Feb. 1830 , CADLC, $2 \mathrm{MD} / 4$, fos. $270-1$.

${ }_{2}$ Mortemart to Polignac, 16 Mar. 1830 , CADLC, $2 \mathrm{MD} / 7$, fos. $45^{-7}$.
} 
worried that an invasion could lead to war in Europe. ${ }^{83}$ Prince Metternich expressed the same anxieties about a European war and remained dismissive of the French designs. ${ }^{8}$

Prospects at this point appeared grim, especially because the diplomatic negotiations between France and Great Britain seemed deadlocked. The situation came to a head as the British cabinet questioned the legitimacy of the invasion. Lord Aberdeen still emphasized the suzerainty of the Ottoman sultan over Algiers and demanded that the Porte should first be allowed to carry out its mediation. Charles X, he noted, could thereby acquire his sought-after redress, while the army that steadily amassed in France's southern ports could serve as an extra source of pressure on Hussein Dey. ${ }_{5}$ In itself, the sheer number of expeditionary troops that was being summoned created serious concerns. The ambassador in Paris, Sir Charles Stuart $\left(1779^{-1845}\right)$, ceaselessly asked Polignac why this army was so large and inquired about the expedition's 'ulterior views'. ${ }^{86}$ With an assembled force that already totalled over 25 , ooo men, it appeared France was going to wage a 'war of extermination'. ${ }^{7} 7$ British officials therefore continued to ask for written statements that the French government harboured no territorial designs on Algiers. These never came. All the while, the Royal Navy was the only maritime force that would be capable of halting the French expedition, and French agents constantly kept an eye on movements in Britain's naval ports. ${ }^{88}$ Concerns about an Anglo-French war even stretched all the way down to the rank and file of the expeditionary army, as the British consul in Marseille reported. ${ }^{89}$

Amidst these tensions, diplomatic debates over the question of piracy and whether it could be suppressed in the manner at hand continued. British officials, backed by their Austrian counterparts, ceaselessly doubted that an expedition would be a proportionate security measure. Both Aberdeen and Wellington repeatedly argued that the 'destruction' of piracy would not warrant a lasting territorial occupation.90 Maintaining that Britain was the only power so mistrustful of France, Polignac reiterated the shared interests at stake in defeating Algiers. 'A plan', he wrote, 'so profitable to all peoples interested in the security of the Mediterranean and oceans, does not seem to be of such a nature that it can cause real disquiet in Europe, or even in England.'91 Drawing from the recent history of concerted security efforts, the French minister utilized the piracy threat to present the invasion as a service

\footnotetext{
83 Mortier to Polignac, 24 Apr. and 19 May 1830 , CADLC, $106 C P / 273$, fos. $15^{\mathrm{o}-62}, 193-9$.

84 Cowley to Aberdeen, 17 Apr. 1830 , TNA, FO $120 / 108$.

85 Stuart de Rothesay to Aberdeen, 26 Feb. 1830 , TNA, FO 27/407, fos. $118-24$.

86 Aberdeen to Stuart de Rothesay, 23 Mar. 1830 , TNA, FO 27/405, fos. 43-5o.

87 Laval to Polignac, 3 Mar. 183o, CADLC, 8CP/63o, fos. 29-33.

88 Laval to Polignac, 10 May and 25 May 1830 , CADLC, 8CP/63o, fos. $230^{-} 5$ and $314^{-19}$.

89 Turnbull to Morrier, 28 May 1830 , TNA, FO 27/410, fos. $91-4$.

$9^{\circ}$ For instance, Laval to Polignac, 21 Apr. 1830 , CADLC, 8CP/63o, fos. 168-72.

$9^{1}$ Polignac to Laval, 5 May 183 o, CADLC, 8CP/63o, fos. 203-1o.
} 
to Europe. While British officials criticized the form of the French measures, and especially their potential consequences, they still left the idea largely unchallenged that France was fighting a collective menace of Algerine pirates.

In an attempt to undercut the British concerns, while refraining from putting anything to paper that touched upon long-term plans, Polignac issued a proposal on 12 May to convene a multilateral conference on the future of Algiers. $9^{2}$ By then, the expeditionary army had gathered in Toulon and was only a few days from its departure. The conference would thus take place after the attack, under the expectation that the French would be victorious. Its intended aim was to find an international solution for Algiers's subsequent status. Once again, the circular containing the invitation not only went to the courts of the great powers, but also to Spain and the various Italian states. Lord Aberdeen wondered whether Britain should even accept the invitation and send a representative. A British attendee would surely find himself outnumbered with his instructions to maintain an 'equilibrium' in the Mediterranean.93 Metternich doubted that the meeting would ever take place. He nevertheless met up with Ambassador Henry Wellesley, Baron Cowley (1773-1847), in Vienna and actively started to prepare for the conference by aligning Austria's and Great Britain's positions.94 Statesmen of the other invited powers also planned ahead. They put an array of proposals to paper that ranged from handing over Algiers to a revived Order of Malta and destroying all the Regency's armaments before returning authority to Sultan Mahmud II, to setting up an allied occupation in the conquered lands, resembling the one initiated in France following Napoleon's final defeat.95

Historians have treated this conference proposal as nothing more than one of Polignac's many diplomatic ploys. They have given the invitation scant attention, based on the anachronism that the meeting never happened, which has great implications for how we see the 1830 invasion. $9^{6}$ As a result, the question of what this proposal signified within the contemporary international system has never been explored. The suggestion of holding a genuine international conference, featuring great power ambassadors as well as a selected cast of smaller power invitees, positioned the invasion of Algiers in a tradition of previous meetings where European officials had discussed shared threats and common practices of security. Polignac's invitation signifies how the question of Algiers was brought into the frameworks of concertation that had painstakingly been put in place in the wake of the Napoleonic Wars through ambassadorial

$9^{2}$ Circular dispatch, 12 May 1830 , CADLC, 2MD/7, fos. 89-92 and $93-7$.

93 Laval to Polignac, 21 Apr. 1830 , CADLC, 8CP/63o, fos. 168-72.

94 Metternich to Appony, 5 June 1830 , HHStA, StAbt, Frankreich, Diplomatische Korrespondenz, 276, fos. $167-72$.

95 Polignac to Rayneval, 20 Apr. 1830 , CADLC, $11 \mathrm{CP} / 4^{12}$, fos. $14^{8}-5^{1}$; Indications de pieces remises au Ministre pour le Conseil du 29 Juin, [n.d.], CADLC, $2 \mathrm{MD} / 5$, fo. 425; Cowley to Aberdeen, 18 July 1830 , TNA, FO $120 / 108$.

$9^{6}$ There is but a brief discussion in Julien, La conquête, pp. 40-1 and 59-6o. 
conferences and international congresses. These structures of the emerging security culture had at earlier stages also been used to manage the perceived threat of 'Barbary piracy' in a concerted manner, which avoided potential conflicts that could arise from its suppression. The conference proposal therefore marks a wholly overlooked degree of continuity.

Besides invoking continuities, the conference and its potential outcomes would also have had a strong legitimizing function. Within the post-1815 system, conferences and congresses worked to legitimate particular diplomatic decisions and courses of action that fit the frameworks of collective security. Decisions at these meetings were recorded in protocols, signed by the attending representatives, and oftentimes annexed by a selection of supporting memoranda. Over the course of the nineteenth century's opening decades, the recorded decisions in these protocols acquired an international legal status. They functioned in a manner that Matthias Schulz has described as a kind of ius publicum europeaum. 97 Although the legality of such protocols remained contested by North African and Ottoman actors, the concerted repression of 'Barbary piracy' does indicate that there were attempts to apply them beyond the European continent as well. A conference on Algiers could therefore potentially help legitimate future French ventures in the Regency, which partially explains why Polignac proposed to convene one. This process of sanctioning interventions through international concertation helped facilitate European imperialism under the post-1 815 system.

Polignac's conference proposal simultaneously points to a significant change occurring within the international system. Divisions of power and the accompanying international hierarchies had gradually shifted by 1830. Whereas France had once been a vanquished power, subjected to an allied occupation and the payment of indemnities, the Polignac ministry tried to situate the country at the forefront of the European system of collective security. In destroying Algiers and the 'piratical' threat it posed, France took the lead in completing a fight for European security that had dragged on for the last fifteen years. With the invitation to convene a conference in Paris, Polignac attempted to let France preside over matters of European security. He was effectively putting himself in the position that British statesmen so often had held, when they convened ambassadorial conferences in London (1816-23), led congress committees on the slave trade (at Vienna, Aix-la-Chapelle, and Verona), and headed the allied council that oversaw the occupation of France $\left(1815^{-18)} .9^{8}\right.$ As we have seen, the outbreak of the war between France and Algiers already had everything to do with questions of rank within the international system. Polignac's conference invitation was but another attempt to assert and attain great power status in accordance with the established practices of collective

97 Schulz, Normen und Praxis, pp. 53, 88, and 348.

$9^{8}$ De Graaf, Fighting terror, ch. 7 . 
security. That is, by seeking concertation and the creation of multilateral coalitions.

Another defining feature of the post-1815 system acted in full force: its dynamics of exclusion. The structures and practices of collective security that were put in place after the Napoleonic Wars in Europe depended as much on the integration of different powers within a single hierarchical order as on the relegation of other, often non-European powers, outside that order. Concerns of the North African authorities, who contested efforts to repress their privateering at various occasions, were routinely brushed aside by European actors. Hussein Dey, for instance, tried to reopen negotiations in late December 1829 , proposing diplomatic talks on Malta to bring the conflict with France to a peaceful solution. The French government responded that talking was now beneath the dignity of the king.99 In contrast, Paris frequently consulted with the Ottoman authorities in Istanbul during the earlier stages of the Franco-Algerine conflict. Nevertheless, the Ottoman insistence that the Regency of Algiers stood under the sultan's suzerainty did not stop the French invasion. In fact, Mahmud II's envoy to Algiers, the naval commander Tahir Pasha (Çengeloğlu Tahir Mehmed Paşa, d. 1851), was stopped by the French Mediterranean fleet and directed to Toulon. There, the Ottoman mediator had to spend a month in quarantine, being released only after the victory of the expeditionary forces. ${ }^{100}$ Such exclusionary efforts negated or over-ruled non-European concerns over sovereignty and legitimacy.

By the time the massive French army had embarked the hundreds of warships and transports on 18 May, it was clear that nothing could now stop the invading forces from crossing the Mediterranean. What role had the international system of collective security played in the preceding weeks? Most significantly, it helped avert whatever potential had existed for war among the European powers. There certainly had been a few tense moments, but historians nowadays consider it unlikely that war would have broken out. They note that the British cabinet was almost exclusively occupied by the domestic issues of a mounting debt crisis and the passing of King George IV on 26 June 1830. ${ }^{101}$ British officials, Šedivý furthermore argues, probably did not find Algiers worth the risk of initiating a great power war, even if they did consider its territories to be of strategic importance. ${ }^{102}$

Alongside these factors, however, the workings of the international system certainly played their part. The French repeatedly offered to act in concert, diplomatic exchanges endured on all sides, and underlying notions of Algiers as a

99 Quin to Bretonnière, 20 Dec. 1829, and Bretonnière to Haggi Khalil Effendy, $3^{1}$ Jan. 1830 , CADLC, $2 \mathrm{MD} / 4$, fos. $15^{6-64}$ and $212-14$.

100 Taher Pasha to Polignac, 27 May 1830 , CADLC, 2 MD/5, fos. $312-15$; Polignac to Taher Pasha, 1 July $1830,2 \mathrm{MD} / 6$, fos. 4-5.

${ }^{101}$ Julien, La conquête, pp. 39-40; Serres, La politique turque, pp. 8o-2; Le Marchand, L'Europe, pp. 203-4.

102 Sedivý, Metternich, pp. 426-7. 
'piratical threat' to Europe remained in place. Polignac's conference invitation further formalized French attempts to align the invasion of Algiers with the international system. If the French expedition was really to the benefit of Europe, the maritime states or 'Christianity', as different memoranda maintained, then obtaining the support of not just the great powers but also their smaller counterparts was of vital importance. This was, in essence, what French diplomacy was most concerned with in the immediate run-up to the invasion. The proposed conference stands as the culmination of this diplomatic effort, as it would have remoulded the informal support of diplomatic correspondences into collective, formalized agreement of the kind that had resulted from many earlier conferences and congresses.

\section{$\mathrm{V}$}

As uncertain as the prospects of a French invasion had been, it proved to be fatally efficient once underway. The troops of the expeditionary army quickly moved into the city of Algiers after taking the beaches of Sidi Ferruch (Sidi Fredj) on 14 June, benefiting from the disarray of the Algerine forces and internal unrest in the Regency. ${ }^{103}$ By 4 July, after hours of steady bombardments, Algiers's main landward fortifications fell to the French. The city's notables congregated that night. They pressed the authorities to treat for peace in a bid to ward off looting and bloody vengeance by the invaders. Hussein Dey surrendered the next morning. He signed a convention that the victors would respect the lives and property of Algiers's inhabitants. The French hoisted their flag over the Dey's palace as the troops swarmed the city and vandalized, confiscated, and murdered in direct defiance of the armistice agreement. ${ }^{104} \mathrm{In}$ Paris, Jules de Polignac received the news of the victory in high spirits, writing jubilantly: 'The security of the Mediterranean is re-established.' ${ }^{105}$ The work, his statement seems to suggest, had ended. France had taken over the fight against 'Barbary piracy', conceived as a European project shaped by the concerted practices of the post-1 815 system.

How the international system fostered the invasion of Algiers becomes more obvious when looking at the diplomatic sources and trying to grasp the contemporary relevance of successive plans - even if many were eventually discarded. French conduct throughout the war centred on the tried and tested ways of European concertation from the earliest stages of the conflict in 1827. The effort to amass foreign support and forge multilateral approval permeated all the different phases of the war. This ranged from Clermont-Tonnerre's initial proposal to the Mehmed Ali scheme and peaked with Polignac's conference invitation. A decided unwillingness to risk great power conflict steered

\footnotetext{
103 McDougall, A history of Algeria, p. $5^{2}$.

104 Ibid., p. $5^{1 .}$

105 Polignac to Laval, 16 July 1830 , CADLC, 8CP/63o, fos. 133-4.
} 
French policies from one phase to the next. Attempts to link the war plans to the lineage of the post-1815 system characterized French diplomacy throughout these phases. Aside from uncovering the invasion's international dynamics, the insights offered in this article also shed new light on the continuities within the post-1 815 system. A closer look at the French invasion of Algiers indicates the longevity of the specific threat perceptions, shared security practices, and legal reasoning that developed under the Congress system. This particular security culture, with its multilateral politics of concertation, thus remained in place after the 1820 s and helped facilitate the 1830 attack on Algiers.

Such continuities even stretched far beyond the French victory, extending past the profound upheaval of the July Revolution of $26-9$ July 1830 . The invasion, despite its military success, did not secure the political future of the Bourbon monarchy. Following hectic elections and some insurgent fervour, the reign of Charles $\mathrm{X}$ made way for a new constitutional monarchy under his cousin Louis Philippe (1773-185o). Many of the Polignac ministry's international plans then disappeared from view, including the conference. ${ }^{106}$ The proposed meeting never materialized and European statesmen soon began to see the lasting French presence in Algiers as a fait accompli, anxious that reneging on the conquest would expose the new monarchy to revived domestic unrest. Again, tranquillity in Europe was intrinsically related to violence and warfare in North Africa. The multilateral management of common interests in the region would also endure, as different European powers and the Ottoman Empire concerted to put bounds on French expansionism when it threatened to infringe upon Tripoli (1835), Tunis (1838), and Morocco $(1844) .{ }^{107}$

Though they certainly were contested and put to the test, shared perceptions of threat, practices of concertation, and common understandings of legality effectively tied the post-1815 international system to imperial expansionism in North Africa, both before and after 183o. Taking a broader perspective, we can ask whether these ties may have played a role in other imperial locations and conflicts around the world. Did similar multilateral dynamics shape roughly contemporaneous events, such as the Dutch Java War (1825-30), the reassertion of direct Ottoman rule over Tripoli (1835), or Russian advances in the Caucasus (1833)? And did the experiences of the 183 os affect later imperial concertation, for instance at the Congress of Berlin (1878)? Without exploring these questions, the post-1 815 system's relation to nineteenth-century imperialism remains obscured. Accordingly, we run the risk of understanding that system solely as a purveyor of peace, tranquillity, and order in Europe, while its global impact was markedly different.

${ }^{106}$ Serres, La politique turque, pp. 62-4.

${ }_{107}$ M. Minawi, The Ottoman scramble for Africa: empire and diplomacy in the Sahara and the Hijaz (Stanford, CA, 2016); Chater, Dépendance et mutations, pp. 501-2; A. Tablit, ed., Le gouvernement marocain et la conquête d'Alger (Algiers, 1999). 